\title{
Sharing of tacit knowledge in volunteer Portuguese firefighters
}

\author{
Márcio Oliveira ${ }^{1}$, Paulo Pinheiro ${ }^{2}$ \\ ${ }^{1}$ Instituto Politécnico de Leiria, Leiria, Portugal \\ ${ }^{2}$ NECE Research Unit in Business Sciences, University of Beira Interior, Covilhã, Portugal \\ marcio.oliveira@ipleiria.pt \\ pgp@ubi.pt
}

\section{ABSTRACT}

The studies in the area of knowledge management, directed to non-profit organizations are scarce, as opposed to what happens in the private and public sector. The growing importance of the third sector and its institutions, in establishing a more just and balanced society, combating asymmetries and placing itself on the side of the neediest, justifies the attention of the academic community, in order to establish and adopt best practices to carry out their missions. The choice of a case study of organizations such as the Portuguese fire brigades (FBs), unique in their action and identity, accompanies the need increasingly recognized by Portuguese society, in enabling these organizations of competencies for the best possible performance, in view of tragic events that have occurred in recent years in this country, particularly in the area of major fires.

Research goal: placing the focus of the study on the sharing of tacit knowledge in these organizations and taking as a case study the Portuguese volunteer firefighter, we set as objectives the verification of the prevalence of tacit knowledge indicators within these organizations and the identification of barriers to this same sharing.

Research methodology / design: a careful reading of the literature on sharing tacit knowledge allowed the identification of possible indicators and barriers to the sharing of this knowledge, which were later included in the script of interviews to eight commanders of fire brigades of the central region of Portugal, under the methodological technique snowball, for a qualitative study.

Main findings: it was possible to conclude that these organizations tend not to share this type of knowledge, presenting barriers at the individual, organizational and technological level.

Limitations / recommendations: as limitations of the research, it should be noted that the present research focuses exclusively on the sharing of tacit knowledge, not considering other forms of knowledge. As a case study, although with heterogeneous organizations, the same cannot be replicated to different realities.

KEYWORDS: Tacit Knowledge, Indicators, Barriers, Volunteer Firefighters, Non-profit Organizations

\section{INTRODUTION}

The sharing of tacit knowledge within organizations, notwithstanding the recognition of the benefits that may result, is not something that is easy to establish as a regular practice. Due to their unique characteristics, NPOs, in the pursuit of their missions, are increasingly having to incorporate this sharing of knowledge. The studies on the prevalence of indicators and what the barriers that are raised to them, in this type of organizations, are scarce. With the objective of verifying the prevalence of tacit knowledge sharing indicators and the main barriers to this sharing, the present article presents the results of a research on sharing tacit knowledge in Portuguese FBs, a type of non-profit organization that performs its action in the area of civil protection and emergency pre hospital. It should be noted that in Portugal there is no other type of organization where its driving force is composed of a combination of purely voluntary elements and employees that provide the minimum daily operational services, with the volunteers assuring the night service and week, where there is an increase in the intervention and availability of these elements in the summer season, with a clear decrease in service in the 
remaining seasons, where the hierarchical structure follows a paramilitary regime, but which may include at the top of its pyramid firefighters who only carry out functions under pure voluntary service, operating in a service area as sensitive as civil protection.

The unit of analysis was selected according to a sample of volunteer fire brigades, which were present in the large fires that occurred during the months of June and October 2017, in Portugal, according to the snowball technique. The choice of this methodology was focused on the fact that we are studying the organizations that participated in an event whose causes or consequences are still being discovered by civil society. In the course of the interviews, new data were found that sent new questions to other commanders of other voluntary fire brigades, until the saturation point of the information was reached, where other interviewees would no longer bring new information of relevance to the investigation.

The article begins with a brief introduction to the subject, followed by the theoretical framework, focusing on indicators and barriers to sharing tacit knowledge. The next point deals with the presentation and discussion of the results. Finally, we present the conclusions and recommendations for future studies.

\section{THEORETICAL FRAMEWORK}

The theoretical framework intended to make a reflection on the tacit knowledge and its sharing, and theoretically substantiate the indicators and barriers studied in this research.

\section{Tacit knowledge and its sharing}

Tacit knowledge refers to a type of knowledge whose description or communication is not easy and whose reflections only gain visibility with the studies of Polanyi $(1962,1966)$. For Nonaka (1994), explicit knowledge is codified and can be easily communicated and transferred, and can be presented in the form of manuals, plans, procedures, among others. In contrast, tacit knowledge is implicit, it is difficult to conceptualize, it is subjective and composed by the experiences of the individual. Polanyi (1966) had described tacit knowledge as something that is known, more than can be said, or as something that allows us to do something without thinking about it. A close look at the literature allows us to establish a set of contributions that help us to understand the difficulties inherent in a process of tacit knowledge sharing within organizations.

\begin{tabular}{|c|l|}
\hline Author & \multicolumn{1}{c|}{ Main focus } \\
\hline $\begin{array}{c}\text { Davenport e } \\
\text { Prusak (1998) }\end{array}$ & $\begin{array}{l}\text { Tacit knowledge is difficult to code in documents or databases, is developed and } \\
\text { internalized for a long period of time and within a specific cultural environment. It } \\
\text { is not always a conscious process and some of this tacit knowledge may not even } \\
\text { be capable of representation outside the mind. }\end{array}$ \\
\hline $\begin{array}{c}\text { Othman e } \\
\text { Abdullah (2010) }\end{array}$ & $\begin{array}{l}\text { Its nature is subjective and intuitive, which leads to a huge loss, for example, when } \\
\text { a very experienced employee leaves the organization to which he belongs. }\end{array}$ \\
\hline $\begin{array}{c}\text { Hislop (2009); } \\
\text { Mládková } \\
\text { (2012) }\end{array}$ & $\begin{array}{l}\text { As tacit knowledge is always stored in the human brain, its sharing is difficult, } \\
\text { complex, time-consuming and one of the greatest challenges for knowledge } \\
\text { management. }\end{array}$ \\
\hline $\begin{array}{c}\text { Nonaka e } \\
\text { Takeuchi }\end{array}$ & $\begin{array}{l}\text { About two thirds of the information received in the work context is transformed } \\
\text { into tacit knowledge through face-to-face interaction, such as informal } \\
\text { conversations, direct interaction, storytelling, mentoring, networking or } \\
\text { internships, which indicates that it is a complex task, which requires communication } \\
\text { between co-workers in order to capture this kind of knowledge. }\end{array}$ \\
\hline al. (2012)
\end{tabular}




\begin{tabular}{|c|l|}
\hline $\begin{array}{c}\text { Goffin e Koners } \\
\text { (2011) }\end{array}$ & $\begin{array}{l}\text { To transfer tacit knowledge requires extensive personal contact, regular interaction } \\
\text { and trust between the parties involved. Tacit knowledge is shared when the holder } \\
\text { or owner joins a network or community. }\end{array}$ \\
\hline $\begin{array}{c}\text { Schmidt e } \\
\text { Hunter (1993) }\end{array}$ & $\begin{array}{l}\text { The sharing of tacit knowledge is done through practice and needs a specific } \\
\text { favorable context. }\end{array}$ \\
\hline Fan et al. (2010) & $\begin{array}{l}\text { It is important to create and shape relationships among co-workers, as well as a } \\
\text { network of relationships that help the sharing and transfer of tacit knowledge } \\
\text { among individuals for the sake of a project. }\end{array}$ \\
\hline $\begin{array}{c}\text { Bloodgood e } \\
\text { (2001); }\end{array}$ & $\begin{array}{l}\text { There are two processes of tacit knowledge sharing: directly through personal } \\
\text { contacts with other employees of the organization and indirectly through } \\
\text { information and communication technologies. In the first case, we can take as an } \\
\text { example the learning obtained through participation in personal meetings, } \\
\text { Szulczynska } \\
\text { (2014) }\end{array}$ \\
$\begin{array}{c}\text { meetings between employees who need support, direct observations, among } \\
\text { others. In the second case, internet and intranet networks, e-mails, databases, } \\
\text { videoconferences, teleconferences, among others, can be considered as examples. }\end{array}$
\end{tabular}

Table 1. Contributions to the understanding of the difficulty of sharing tacit knowledge

According to Fotler (1981), the organizations that operate in this sector operate in very dynamic and complex contexts, whose studies can lead to valuable conclusions about organizational behaviour. The reference to uncertainty and lack of financial stability (Gronbjerg 1991), the heterogeneity and ephemerality of human resources (Ragsdell 2013) are among the references of environmental complexity in which NPOs operate and can influence this sharing, cultural specificity (De Long and Fahey 2000) and organizational structure (Webster and Wong 2008).

\section{Indicators of tacit knowledge sharing within organizations}

Thus, in order to be able to ascertain the existence of tacit knowledge sharing within an organization, it was possible to compile a set of indicators that are echoed in the literature and that we adopted for the present study, as shown in table 2 .

\begin{tabular}{|c|c|c|}
\hline Indicators & Authors & Main focus \\
\hline $\begin{array}{l}\text { 1. Individual } \\
\text { Time } \\
\text { Management }\end{array}$ & $\begin{array}{c}\text { Haldin-Herrgard } \\
\text { (2000), Fahey e } \\
\text { Prusak (2001) }\end{array}$ & $\begin{array}{l}\text { The dissemination of knowledge comprises a set of tasks that, } \\
\text { due to their slowness, may not be compatible with the speed in } \\
\text { the business world. Tacit knowledge sharing still requires more } \\
\text { time to be effective by comparison to explicit knowledge sharing. }\end{array}$ \\
\hline $\begin{array}{l}\text { 2. Common } \\
\text { language }\end{array}$ & $\begin{array}{l}\text { Szulanski } \\
\text { (1996), Haldin- } \\
\text { Herrgard (2000), } \\
\text { Davenport e } \\
\text { Prusak (1998) e } \\
\text { Disterer (2003) }\end{array}$ & $\begin{array}{l}\text { In order for a tacit knowledge transfer process to be effective and } \\
\text { efficient, communication failures between the sender and the } \\
\text { receiver cannot be verified, so the terminology and the } \\
\text { expressions used, which often assume their own connotation } \\
\text { depending on the organizational context in which are used, must } \\
\text { be of the full knowledge of the parties. }\end{array}$ \\
\hline 3. Mutual Trust & $\begin{array}{l}\text { Davenport e } \\
\text { Prusak (1998) }\end{array}$ & $\begin{array}{l}\text { The risks and uncertainties in the sharing of tacit knowledge are } \\
\text { smaller, the greater the trust between the individuals that make } \\
\text { up the organization. Establishing a trust network depends on } \\
\text { shared social, cultural values and common expectations. }\end{array}$ \\
\hline
\end{tabular}




\begin{tabular}{|c|c|c|}
\hline $\begin{array}{l}\text { 4. Relationship } \\
\text { network }\end{array}$ & $\begin{array}{c}\text { Szulanski } \\
\text { (1996), O'Dell e } \\
\text { Grayson (1998) }\end{array}$ & $\begin{array}{l}\text { One of the difficulties in sharing tacit knowledge comes from a } \\
\text { weak diagnosis about the identification of the needs of tacit } \\
\text { knowledge that each element of the organization must have and } \\
\text { about the quantity and quality of knowledge to be acquired to } \\
\text { meet this need. Both the recipient and the issuer of the } \\
\text { knowledge do not know who in the organization can hold or be } \\
\text { interested in the knowledge that is lacking or that they have. }\end{array}$ \\
\hline 5. Hierarchy & $\begin{array}{l}\text { Disterer (2003), } \\
\text { O'Dell e } \\
\text { Grayson (1998) }\end{array}$ & $\begin{array}{l}\text { The hierarchical and bureaucratized organizational structures } \\
\text { hinder communication, information sharing and, ultimately, the } \\
\text { sharing of tacit knowledge. Each element acts in order to achieve } \\
\text { and enhance its own results and rewards, which discourages the } \\
\text { exchange of experiences. }\end{array}$ \\
\hline $\begin{array}{l}\text { 6. Recognition } \\
\text { and reward }\end{array}$ & $\begin{array}{l}\text { Szulanski } \\
\text { (1996), Disterer } \\
\text { (2003) e Haldin- } \\
\text { Herrgard (2000) }\end{array}$ & $\begin{array}{l}\text { Organizations should recognize and reward their elements so } \\
\text { that they feel motivated to continue sharing their knowledge. } \\
\text { Sharing other forms of tacit knowledge as know-how should be } \\
\text { as rewarded as the sharing of knowledge through formal } \\
\text { education. }\end{array}$ \\
\hline $\begin{array}{l}\text { 7. Type of } \\
\text { training for the } \\
\text { task }\end{array}$ & $\begin{array}{l}\text { Joia (2007), } \\
\text { Disterer (2003) } \\
\text { e Leonard e } \\
\text { Sensiper (1998) }\end{array}$ & $\begin{array}{l}\text { These are forms of training provided by more experienced } \\
\text { employees who are encouraged to pass on their knowledge to } \\
\text { younger employees, always in a work or organizational context. } \\
\text { Coaching and mentoring are understood to be the most } \\
\text { appropriate techniques when it comes to tacit knowledge } \\
\text { sharing. }\end{array}$ \\
\hline $\begin{array}{c}8 . \\
\text { Transmission } \\
\text { of knowledge }\end{array}$ & $\begin{array}{l}\text { Nonaka e } \\
\text { Takeuchi (1995), } \\
\text { Leonard e } \\
\text { Sensiper (1998), } \\
\text { Hansen, Nohria } \\
\text { e Tierney (1999) } \\
\text { e Joia (2007) }\end{array}$ & $\begin{array}{l}\text { The knowledge transfer strategy of an organization can be } \\
\text { focused on the people or the reuse of codified knowledge. If the } \\
\text { organization privileges the interaction between the people that } \\
\text { compose it, the focus is on the dialogue and interaction between } \\
\text { them, because it is through this personal contact that knowledge } \\
\text { is transmitted. If one prioritizes the re-use of codified knowledge, } \\
\text { it must be stored in databases that can be consulted and used by } \\
\text { all elements of the organization, and there is no great interaction } \\
\text { between people, but between people and technology. }\end{array}$ \\
\hline $\begin{array}{l}\text { 9. Knowledge } \\
\text { storage }\end{array}$ & $\begin{array}{l}\text { Hansen, Nohria } \\
\text { e Tierney (1999) }\end{array}$ & $\begin{array}{l}\text { When the focus of knowledge storage is database oriented, the } \\
\text { organization tends to explicitly manage explicit knowledge, } \\
\text { whereas when the focus of knowledge storage is people- } \\
\text { oriented, the organization tends to practice tacit knowledge } \\
\text { management. }\end{array}$ \\
\hline 10. Power & $\begin{array}{c}\text { Szulansky } \\
\text { (1996), } \\
\text { Davenport e } \\
\text { Prusak (1998) e } \\
\text { Disterer (2003) } \\
\end{array}$ & $\begin{array}{l}\text { The perception of loss of influence, of dominant job position over } \\
\text { others, of professional respect or job security, can inhibit the } \\
\text { sharing of knowledge. }\end{array}$ \\
\hline $\begin{array}{c}11 . \\
\text { Environment } \\
\text { favorable to } \\
\text { questioning }\end{array}$ & $\begin{array}{l}\text { Sun e Scott } \\
\quad(2005)\end{array}$ & $\begin{array}{l}\text { The lack of this psychologically safe environment to express } \\
\text { different opinions and ideas is a factor that compromises the } \\
\text { sharing of tacit knowledge in an organization. }\end{array}$ \\
\hline $\begin{array}{l}\text { 12. Type of } \\
\text { Valued } \\
\text { Knowledge }\end{array}$ & $\begin{array}{l}\text { Lemos e Joia } \\
\qquad(2012)\end{array}$ & $\begin{array}{l}\text { Various forms of tacit knowledge such as personal skills or } \\
\text { intuition may not be recognized or valued by some organizations. }\end{array}$ \\
\hline $\begin{array}{l}13 . \\
\text { Comunication }\end{array}$ & $\begin{array}{l}\text { Leonard e } \\
\text { Sensiper (1998) } \\
\text { e Haldin- } \\
\text { Herrgard (2000) }\end{array}$ & $\begin{array}{l}\text { Personal conversation is the richest form of communication } \\
\text { because it enables mutual and immediate feedback and the use } \\
\text { of multiple forms of communication such as demonstration of } \\
\text { personal skills and even the use of body language. }\end{array}$ \\
\hline
\end{tabular}

Table 2. Tacit knowledge sharing indicators 


\section{Barriers to tacit knowledge sharing: personal, organizational and technological}

However, this analysis will be more complete if the prevalence of indicators can be associated with the barriers to tacit knowledge sharing in this organizational context. Thus, the typologies of barriers equated for the present study and presented in the literature are presented in table 3.

\begin{tabular}{|c|c|c|}
\hline Typology & Author & Contribution \\
\hline \multirow[b]{2}{*}{ Individual } & Riege (2007); & $\begin{array}{l}\text { Barriers to knowledge sharing are usually related to factors such as } \\
\text { lack of communication skills and social networks, cultural } \\
\text { differences, excessive emphasis on status of the position occupied } \\
\text { and lack of time and confidence. }\end{array}$ \\
\hline & $\begin{array}{l}\text { Para Awad e } \\
\text { Ghaziri } \\
\text { (2007); } \\
\text { Mohajan } \\
\text { (2016) }\end{array}$ & $\begin{array}{l}\text { Personality, temperament, attitude, interpersonal skills, and pride in } \\
\text { ownership or the idea of being the exclusive possessor of something } \\
\text { are individual factors that make it difficult to share tacit knowledge. } \\
\text { In some cases, individuals avoid sharing knowledge because of the } \\
\text { risk of exposing their knowledge. }\end{array}$ \\
\hline \multirow{4}{*}{ Organizational } & $\begin{array}{l}\text { Joia e Lemos } \\
\text { (2010) }\end{array}$ & $\begin{array}{l}\text { The reason of being an organization more or less bureaucratic, } \\
\text { hierarchical and inflexible, and therefore more difficult to share tacit } \\
\text { knowledge, often based on the decisions of their leaders. }\end{array}$ \\
\hline & $\begin{array}{l}\text { Awad e } \\
\text { Ghaziri } \\
(2007)\end{array}$ & $\begin{array}{l}\text { The building confidence among its members provides an } \\
\text { organizational environment favorable to the sharing of tacit } \\
\text { knowledge, but that trust can be broken when individuals fail to } \\
\text { recognize the source of that knowledge }\end{array}$ \\
\hline & $\begin{array}{l}\text { Housel e Bell } \\
\qquad(2001)\end{array}$ & $\begin{array}{l}\text { Actions such as restructuring or downsizing lead to a loss of valuable } \\
\text { knowledge in organizations, or simply, when an individual who has a } \\
\text { great skill or ability leaves the organization without it may have } \\
\text { taken care of its replacement by someone previously prepared for } \\
\text { the purpose. }\end{array}$ \\
\hline & Riege (2005) & $\begin{array}{l}\text { Excessive employee competitiveness, high staff turnover, limited } \\
\text { access to resources that prevents the organization from recognizing } \\
\text { or rewarding its employees, the prevalence of unilateral top-down } \\
\text { communication, lack of transparency of the organization, or even } \\
\text { lack of staff highly qualified and experienced. }\end{array}$ \\
\hline \multirow[b]{2}{*}{ Technological } & $\begin{array}{l}\text { Awad e } \\
\text { Ghaziri } \\
(2007)\end{array}$ & $\begin{array}{l}\text { Organizations that only invest in systems and processes of } \\
\text { information and communication technologies are over-reliant on this } \\
\text { technology and invest little in the individual knowledge of their } \\
\text { employees, which can undermine the management of tacit } \\
\text { knowledge. }\end{array}$ \\
\hline & Riege (2005) & $\begin{array}{l}\text { Insufficiency of the technology to respond to the tasks requested, } \\
\text { their inadequacy in relation to the needs of the members of the } \\
\text { organization, their inadequacy due to the need to communicate with } \\
\text { the elements of the organization, the complexity of its use by the } \\
\text { organization's members, its incapacity to enhance the performance } \\
\text { of the organization elements and a poor technical support for their } \\
\text { maintenance. }\end{array}$ \\
\hline
\end{tabular}

Table 3. Types of barrier barriers to knowledge sharing

\section{DATA COLLECTION AND METHODOLOGY}

In pursuit of the objectives, a case study of a type of NPO in Portugal, the voluntary FBs was carried out, without the pretension of generalization or extrapolation, since tacit knowledge is intrinsically related to the environment in which it is developed. It was decided to carry out a qualitative research, for which a set of semistructured interviews was carried out, with a pre-approved script, but with sufficient openness to change the order of the questions applied to FB commanders from the central region of Portugal. The interview questions 
dealt with the demographic data of the interviewees and their experience, a set of questions to ascertain the prevalence of tacit knowledge sharing indicators and another set of questions to determine the main barriers associated with this sharing. The technique used to select the sample was the snowball technique, with the 8 interviews (Commanders of the volunteer firefighters of Brasfemes, Oliveira do Hospital, Anadia, Góis, Loriga, Penela, Guarda and Miranda do Corvo) carried out between the July 12 and August 24, 2018.

\section{PRESENTATION AND DISCUSSION OF RESULTS}

The presentation and discussion of results is divided into two parts, Part I of which relates to data on tacit knowledge sharing indicators within FBs, while Part II concerns data on barriers to sharing of tacit knowledge in the same FBs.

\section{Part I - Sharing Tacit Knowledge Indicators}

Then, we will present the results of the content analysis of the interviews conducted, by indicator. From the analysis of table 4 it is possible to verify that of the 13 indicators under study only four are clearly verified as existing in most of the FBs interviewed. These are the indicators "network of relationship", "storage of knowledge", "type of knowledge valued" and "communication". With the verification of the "relationship network" indicator, it is possible to perceive that in the FBs it is possible to ascertain who are the people who have the knowledge that is needed for an effective sharing of tacit knowledge. By checking the indicator "knowledge storage" it is possible to perceive that the knowledge of the organization is effectively stored in the people who are part of it. By checking the indicator "type of knowledge valued", it is possible to verify that suggestions or ideas that reach the organization by elements that are not based on data or facts are valued and accepted. Finally, with the verification of the "communication" indicator, it can be concluded that personal conversations are the most used form of communication by people who have important knowledge for the daily tasks of the organization.

This is followed by an indicator in which only half of the respondents recognize that their FB prevails, is the "environment favorable to questioning" indicator. The remaining 8 indicators are not found in most of the FBs interviewed, and the "recognition and reward" and "type of training for the task" indicators were not identified as existing in any FB.

\begin{tabular}{|c|c|c|c|c|c|c|c|c|c|c|c|c|c|c|c|c|}
\hline & \multicolumn{2}{|c|}{ Brasfemes } & \multicolumn{2}{|c|}{ Anadia } & \multicolumn{2}{|c|}{ Ol. Hospital } & \multicolumn{2}{|c|}{ Góis } & \multicolumn{2}{|c|}{ Loriga } & \multicolumn{2}{|c|}{ Penela } & \multicolumn{2}{|c|}{ Guarda } & \multicolumn{2}{|c|}{ M. Corvo } \\
\hline Indicator & 岀 & $z$ & 苟 & z & 面 & z & 贸 & z & 惫 & z & 勇 & z & 忘 & z & 䍖 & z \\
\hline $\begin{array}{c}\text { Individual } \\
\text { Time } \\
\text { Management } \\
\end{array}$ & & $x$ & & $\mathrm{x}$ & & $x$ & & $\mathrm{x}$ & & $x$ & $x$ & & & $\mathrm{x}$ & & $x$ \\
\hline $\begin{array}{l}\text { Common } \\
\text { language }\end{array}$ & $\mathrm{x}$ & & & $\mathrm{x}$ & $x$ & & & $\mathrm{x}$ & & $x$ & $x$ & & & $x$ & & $x$ \\
\hline Mutual Trust & $x$ & & & $x$ & & $x$ & & $x$ & & $x$ & $x$ & & & $x$ & & $x$ \\
\hline $\begin{array}{c}\text { Relationship } \\
\text { network }\end{array}$ & $\mathrm{x}$ & & & $\mathrm{x}$ & $x$ & & $x$ & & $\mathrm{x}$ & & $\mathrm{x}$ & & $\mathrm{x}$ & & $x$ & \\
\hline Hierarchy & & $x$ & & $x$ & $x$ & & & $x$ & $x$ & & $x$ & & & $x$ & & $x$ \\
\hline $\begin{array}{l}\text { Recognition } \\
\text { and reward }\end{array}$ & & $x$ & & $\mathrm{x}$ & & $x$ & & $x$ & & $x$ & & $x$ & & $x$ & & $x$ \\
\hline $\begin{array}{c}\text { Type of } \\
\text { training for } \\
\text { the task }\end{array}$ & & $x$ & & $x$ & & $\mathrm{x}$ & & $\mathrm{x}$ & & $\mathrm{x}$ & & $x$ & & $\mathrm{x}$ & & $x$ \\
\hline
\end{tabular}




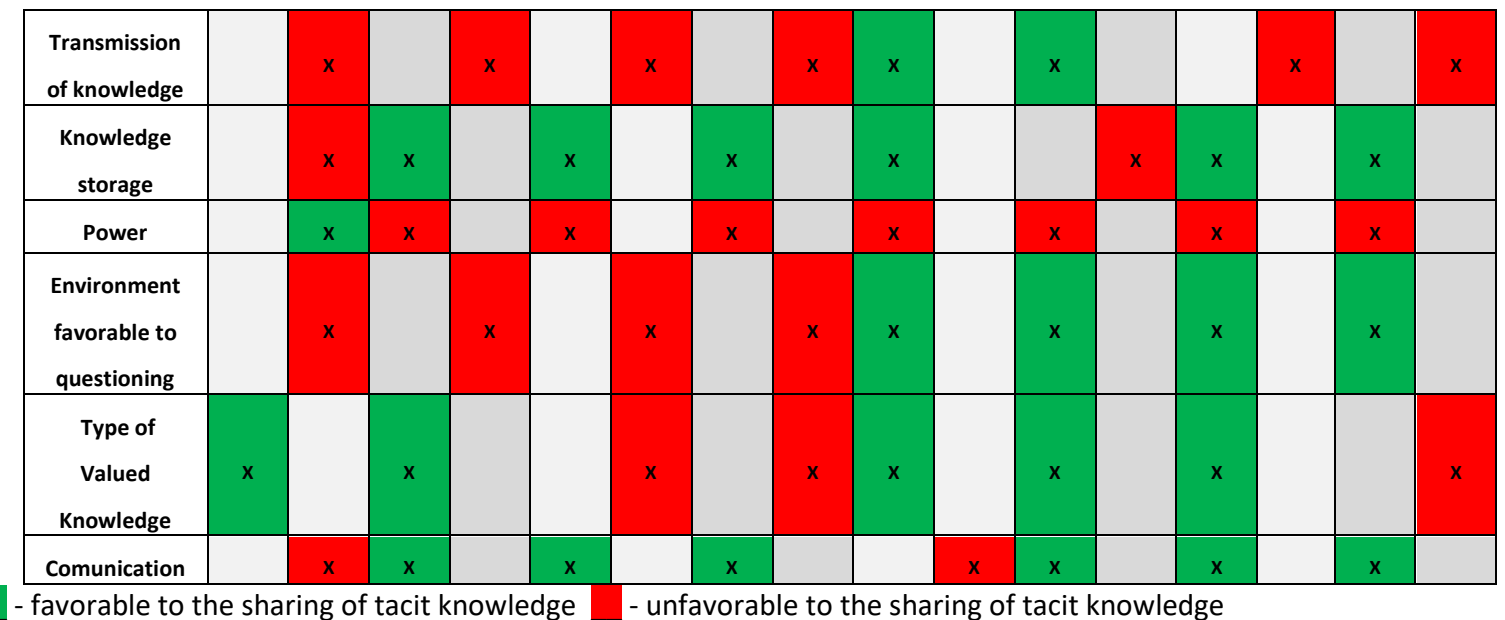

Table 4. Indicators of sharing tacit knowledge in FBs

\section{Part II. Barriers to the sharing of tacit knowledge}

Next, the data on the personal, organizational and technological barriers most prevalent in this study will be presented and discussed.

With the answer to the type of barriers "Personal Barriers" we intend to ascertain the main personal barriers to the sharing of tacit knowledge in the organization under study. It was possible to conclude that the respondents present very different answers, according to diverse data framing the social, economic, demographic and geographical reality in which their FB is inserted. Since the present case study favored FBs with these distinct characteristics so that they could be represented here, uniformity was not expected in the responses, which came to be confirmed, since only 6 of the 21 potential barriers addressed for this study were not indicated by any interviewee.

\begin{tabular}{|c|c|c|c|c|c|c|c|c|c|}
\hline $\begin{array}{l}\text { Types of } \\
\text { barriers }\end{array}$ & Barrier & 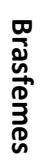 & 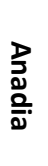 & 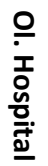 & o: & 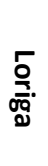 & $\begin{array}{l}\text { D } \\
\stackrel{\mathbb{D}}{\vec{D}} \\
\frac{\mathbb{D}}{\mathbb{N}}\end{array}$ & $\begin{array}{l}\frac{0}{2} \\
\frac{2}{2} \\
\frac{2}{2}\end{array}$ & $\begin{array}{l}3 \\
\grave{\delta} \\
\frac{\delta}{2}\end{array}$ \\
\hline \multirow{7}{*}{ PERSONAL } & Lack of time to share knowledge. & $X$ & & & & $X$ & & $x$ & $x$ \\
\hline & $\begin{array}{l}\text { Lack of time to identify colleagues who need } \\
\text { knowledge. }\end{array}$ & & & & & $X$ & $\mathrm{X}$ & & \\
\hline & $\begin{array}{l}\text { Sharing knowledge is an overload of existing and } \\
\text { available information. }\end{array}$ & & & & & & $X$ & $\mathrm{X}$ & \\
\hline & $\begin{array}{l}\text { Coexistence of different levels of experience in the } \\
\text { various elements of the organization. }\end{array}$ & & & & $X$ & & & & $X$ \\
\hline & $\begin{array}{l}\text { Different generations or large age differences } \\
\text { hampers knowledge sharing. }\end{array}$ & & $X$ & $X$ & $x$ & & & $\mathrm{X}$ & \\
\hline & $\begin{array}{l}\text { Different educational levels hinder knowledge } \\
\text { sharing. }\end{array}$ & & & $X$ & $X$ & & & & \\
\hline & $\begin{array}{l}\text { Lack of confidence in the accuracy and credibility of } \\
\text { knowledge of other elements. }\end{array}$ & & $X$ & & $X$ & & & & \\
\hline \multirow{2}{*}{$\begin{array}{l}\text { ORGANIZAT } \\
\text { IONAL }\end{array}$} & $\begin{array}{l}\text { Knowledge sharing initiatives are not recognized } \\
\text { and rewarded. }\end{array}$ & $X$ & $X$ & & $X$ & $X$ & & $X$ & $X$ \\
\hline & $\begin{array}{l}\text { Low rates of retention of knowledge by the most } \\
\text { experienced elements. }\end{array}$ & & $X$ & & $\mathrm{x}$ & $X$ & $X$ & & $X$ \\
\hline
\end{tabular}




\begin{tabular}{|c|l|l|l|l|l|l|l|l|l|}
\hline \multirow{2}{*}{$\begin{array}{c}\text { TECNOLOGI } \\
\text { CAL }\end{array}$} & $\begin{array}{l}\text { Information technologies are not adequate to } \\
\text { communicate with the elements of the } \\
\text { organization. }\end{array}$ & $\begin{array}{l}\text { Difficult handling of existing information } \\
\text { technologies in the organization. }\end{array}$ & $\mathrm{x}$ & $\mathrm{x}$ & & $\mathrm{X}$ & & & \\
\hline
\end{tabular}

Table 5. Main barriers to sharing tacit knowledge in FBs

Thus, the personal barriers most frequently identified by the interviewees are the lack of time for knowledge sharing and coexistence within the organization of different generations or elements with large age differences. Each of these barriers is identified by half the respondents. Regarding the other personal barriers pointed out by the interviewees, it is important to say that 5 of these barriers are identified in two FBs. They are the lack of time to identify colleagues who need knowledge, knowledge sharing to be seen as an overload of existing and available information, the coexistence of different levels of experience in the various elements of the organization, the coexistence of different educational levels and lack of confidence in the rigor and credibility of the knowledge of the other elements.

Regarding organizational barriers, despite the fact that the present study has presented as a possible answer 12 possibilities of response, it was possible to verify that these are essentially centered around two great organizational barriers, mentioned by a clear majority of respondents and that five potential organizational barriers suggested as a possibility of response were not mentioned by any interviewees. The most referenced organizational barrier, with six interviewees mentioning this issue, is the one that tells us that knowledge sharing initiatives are not recognized or rewarded. In addition to the greater prevalence of this barrier in respondents' answers, another barrier arises with many references, five in the total of respondents. This is the organizational barrier that leads us to the low rate of retention of knowledge by the most experienced elements.

With the answer to the type of barriers "technological barriers" we intend to ascertain the main technological barriers to the sharing of tacit knowledge in the organizations under study. In spite of the fact that the present study has presented as a possible response 6 possible technological barriers, it is possible to verify that the answers are essentially centered around two technological barriers, mentioned by three interviewees. We are dealing with the barriers that indicate to us that information technologies are not adequate to communicate with the members of the organization, that their handling is difficult.

\section{CONCLUSIONS AND RECOMMENDATIONS}

It is possible to conclude that the FBs do not have any measures in place to increase tacit knowledge sharing, so it can be said that, in practice, tacit knowledge sharing is not practiced within the $\mathrm{FB}$, although the prevalence of some indicator's relationship network, storage knowledge, kind of valued knowledge and communication.

It was possible to verify that there are barriers of three different typologies, namely personal, organizational and technological barriers, and the diversity of the socioeconomic, cultural and demographic characteristics of the territory where the FBs studied are matched corresponds to the heterogeneity of the barriers identified. At the personal level, barriers related to lack of time, confidence, information overload and the very heterogeneous characteristics of the elements that compose these FBs were identified as more prevalent. At the organizational level, the lack of recognition and reward for this sharing and the lack of capacity to retain tacit knowledge of the more experienced elements have been more commonly reported. At the technological level, the inadequacy and difficult handling of the technology at the disposal of firefighters was pointed out with greater prevalence. 
Finally, it is recommended to carry out other studies that analyse the sharing of tacit knowledge in other NPOs. It is also suggested to carry out studies that aim to present solutions to better overcome the barriers identified in these NPOs.

\section{BIBLIOGRAPHY}

Awad, E.M. and Ghaziri, H. (2007) Knowledge management. Delhi: Pearson Education.

Bloodgood, J. and Salisbury, W. (2001) "Understanding the Influence of Organizational Change Strategies on Information Technology and Knowledge Management Strategies", Decision Support Systems, 31: 55-69.

Davenport, T.H. and Prusak, L. (1998) Working knowledge: How Organizations Manage What They Know, Boston, Massachusetts: Harvard Business School Press.

De Long, D.W. and Fahey, L. (2000) Diagnosing cultural barriers to knowledge management, Academy of Management Executive, 14(4), pp. 113-127.

Disterer, G. (2003) “Fostering knowledge sharing: why and how?” In: IADIS International Conference E-Society, Lisbon.

Fahey, L. and Prusak, L. (1998) "The eleven deadliest sins of knowledge management", California Management Review, v. 40, n. 3, p. 265-276.

Fan, Yi.-W. and Ku, E. (2010) "Customer Focus, Service Process Fit and Customer Relationship Management Profitability: The Effect of Knowledge Sharing", The Service Industries Journal, 30(2): 203-223. Web: http://dx.doi.org/10.1080/02642060802120141

Fotler, M. D. (1981) “Is management really generic?”, Academy of Management Review, 6(1), pp. 1-12.

Goffin, K. and Koners, U. (2011) "Tacit Knowledge, Lessons Learnt, and New Product Development", Journal of Product Innovation Management, 28 (2): 300-318.

Gronbjerg, K. A. (1991) “How nonprofit human service organizations manage their funding sources: Key findings and policy implications", Nonprofit Management and Leadership, 2, pp. 159-175.

Haldin-Herrgard, T.H. (2000) "Difficulties in the Diffusion of Tacit Knowledge in Organizations", Journal of Intellectual Capital, 1(4): 357-365.

Hansen, M., Nohria, N. and Tierney, T. (1999) “What's your strategy for managing knowledge?", Harvard Business Review, p.1-10.

Hislop, D. (2009) Knowledge management in organizations: a critical introduction, 2nd edition, Oxford University Press, New York.

Housel, T. J. and Bell, A. H. (2001) Measuring and managing knowledge. McGraw-Hill Irwin, Boston.

Jóia, L. A. (2007) “Knowledge Management Strategies: Creating and Testing a Measurement Scale", International Journal of Learning and Intellectual Capital, v. 4, n. 3, p. 203-221. http://dx.doi.org/10.1504/IJLIC.2007.015607

Lemos, B. and Jóia, L. A. (2012) "Relevant factors for tacit knowledge transfer within organizations: an exploratory study", Gestão \& Produção, v. 19, n. 2, p. 233-246.

Leonhard, D. and Sensiper, S. (1998) "The role of tacit knowledge in group innovation", California Management Review, 40(3):112-25.

Majewska, M. and Szulczyńska, U. (2014) "Methods and Practices of Tacit Knowledge SharingWithin an Enterprise: An Empirical Investigation", Oeconomia Copernicana, 5(2): 35-48, Web: http://dx.doi.org/10.12775/OeC.2014.012

Mládková, L. (2012) "Sharing Tacit Knowledge within Organizations: Evidence from the Czech Republic", Global Journal of Business Research, 6(2): 105-115. Web: http://dx.doi.org/10.4135/9781446217375 
Mohajan, H. M. (2016) "Sharing of tacit knowledge in organizations: A Review", American Journal of Computer Science and Engineering, 3(2), 6-19.

Mongkolajala, H., Panichpathom, S. and Ngarmyarn, A. (2012) "The Development of Tacit Knowledge Sharing behavior among Employees in Organizations", International Journal of Business and Social Research, 2(5): 158163.

Nonaka, I. (1994) “A dynamic theory of organizational knowledge creation”, Organization Science, 5(1): 14-37.

Nonaka I. and Takeuchi H. (1995) The knowledge creating company: how Japanese companies create the dynamics of innovation, Oxford: Oxford University Press.

O’Dell, C. and Grayson, C. J. (1998) "If only we knew what we know: identifcation and transfer of internal best practices", California Management Review, v. 40 n. 3, p. 154-174

Othman, A. K. and Abdullah, H. S. (2010) "The Influence of Emotional Intelligence on Tacit Knowledge Sharing in Service Organizations", Knowledge Management in Emerging Economies: Social, Organizational and Cultural Implementation: 171-185.

Polanyi, M. (1962) Tacit knowing: its bearing on some problems of philosophy. Knowing and being: essays by M. Polanyi. London: Routledge and Keagan.

Polanyi, M. (1966) The tacit dimension. Chicago: University of Chicago Press.

Ragsdell, G. (2013) "Voluntary Sector Organisations: Untapped Sources of Lessons for Knowledge Management", In Proceedings of the 10th International Conference on Intellectual Capital, Knowledge Management and Organisational Learning (ICICKM-2013), pp.349-354.

Riege, A. (2005) "Three-Dozen Knowledge-Sharing Barriers Managers Must Consider", Journal of Knowledge Management, 9(3):18-35.

Riege, A., (2007) "Actions to overcome knowledge transfer barriers in MNCs", Journal of Knowledge Management, vol. 11, no. 1, pp.48-67.

Schmidt, F. L. and Hunter, J. E. (1993) "Tacit Knowledge, Practical Intelligence, General Mental Ability, and Job Knowledge", Current Directions in Psychological Science, 2: 8-9.

Sun, P. e Scott, J. (2005) "An investigation of barriers to knowledge transfer", Journal of Knowledge Management, v. 9, n. 2, p. 75-90, 2005. http://dx.doi.org/10.1108/13673270510590236

Szulanski, G. (1996) "Exploring Internal stickiness: impediments to the transfer of best practice within the firm", Strategic Management Journal, v. 17, p. 27-43.

Webster, J. and Wong, W. (2008) "Comparing traditional and virtual group forms: identity, communication and trust in naturally occurring project teams", International Journal of Human Resource Management, 19(1), pp. 41-62. 